\title{
Abrasion Resistance of S235, S355, C45, AISI 304 and Hardox 500 Steels with Usage of Garnet, Corundum and Carborundum Abrasives
}

\author{
Mirosław Szala1*, Michał Szafran², Wojciech Macek ${ }^{3,4}$, Stanislav Marchenko ${ }^{5}$, \\ Tadeusz Hejwowski ${ }^{1}$
}

1 Department of Materials Engineering, Mechanical Engineering Faculty, Lublin University of Technology, Nadbystrzycka 36, 20-618 Lublin, Poland

${ }^{3}$ Technology of materials - Students Scientific Research Group, Mechanical Engineering Faculty, Lublin University of Technology, Nadbystrzycka 36, 20-618 Lublin, Poland

3 Energopiast Sp. z o.o., Polna 12, 55-011 Siechnice, Poland

${ }^{4}$ Wroclaw School of Information Technology, ul. Ks. M. Lutra 4, 54-239 Wrocław, Poland

${ }^{5}$ Sumy State University, 2, Rymskogo-Korsakova st., 40007 Sumy, Ukraine

* Corresponding author's e-mail: m.szala@pollub.pl

\begin{abstract}
The steel presents a wide field of application. The abrasive wear resistance of steel relies mainly on the microstructure, hardness as well as on the abrasive material properties. Moreover, the selection of a abrasion-resistant grade of steel still seems to be a crucial and unsolved problem, especially due to the fact that the actual operating conditions can be affected by the presence of different abrasive materials. The aim of this work was to determine the effect of different abrasive grit materials i.e. garnet, corundum and carborundum on the abrasive wear result of a commonly used in industry practice steels i.e. S235, S355, C45, AISI 304 and Hardox 500. The microstructure of the steel was investigated using light optical microscopy. Moreover, hardness was measured with Vickers hardness tester. Additionally, the size and morphology of the abrasive materials were characterized. The abrasion tests were conducted with the usage of T-07 tribotester (dry sand rubber wheel). The results demonstrate that the hardness and structure of steels and hardness of abrasive grids influenced the wear results. The abrasive wear behavior of steels was dominated by microscratching and microcutting wear mechanisms. The highest mass loss was obtained for garnet, corundum, and carborundum, respectively. The usage of various abrasives results in different abrasion resistance for each tested steel grade. The AISI 304 austenitic stainless steel presents an outstanding abrasive wear resistance while usage of corundum and Hardox 500 while using a garnet as abrasive material. The C45 carbon steel was less resistant than AISI 304 for all three examined abrasives. The lowest resistance to wear in garnet and carborundum was obtained for the S235JR and S355J2 ferritic-perlitic carbon steels and in corundum for Hardox 500 which has tempered martensitic structure.
\end{abstract}

Keywords: abrasion, wear resistance, dry sand-rubber wheel test, garnet, Aluminum oxide, Silicon carbide, steel, hardness, microstructure

\section{INTRODUCTION}

The wear resistance is a crucial feature that affects the engineering of reliability systems. The conveyors, mixers, rotors, the buckets of excavators or loaders, sliding bearings, tools and many more machine components are in contact with free grains of abrasive materials [1-4]. The abrasive wear is defined [1] as the displacement of material caused by the presence of hard particles, of hard particles between or embedded in one or both of the two surfaces in relative motion, or by the presence of hard protuberances on one or both of the 
relatively moving surfaces. Additionally, according to the literature $[5,6]$ the abrasive wear seems to be a dominant wear process - the wear of mechanical parts, about $50 \%$ (of the parts) works in abrasive wear, $15 \%$ - adhesive wear, $8 \%$ - erosion, $8 \%$ - fretting, $5 \%$ - wear is due to corrosion and about $14 \%$ is just a combination of abrasive, erosive and corrosive wear.

Investigation into the wear resistance of ferrous alloys is still an important problem; consequently, many authors research into the sliding [7,8], abrasion [2,9], erosion [10,11], corrosion [12-14] or cavitation erosion $[8,15]$ wear resistance of commercial steels such as S235, S355, C45, AISI 304 and Hardox 500. However, the information about the steel wear properties examined for a wider group of commercial materials is limited. For example, Zambrano et al. [16] investigated the sliding wear resistance of selected steels (AISI 5160, AISI 1045 and AISI O1). However, the tested group of materials presents the same hardness or in another work [9] investigated and compared the abrasive resistance of only the austenitic steel group (grades FeMnAlC steel, AISI 316L and Hadfield steel). Therefore, it is necessary to combine the results for a broader range of materials. Thus, the current work is focused on examining the three carbon steels commonly used in industrial practice: S235 and S355, C45 (popular structural materials) which were compared with classic stainless steel grade X5CrNi18-10 (AISI 304) and with Hardox 500 , the low-alloy abrasive-wear resistant steel that is gaining favor [2, 17-22]. Therefore, the steel materials investigated in current work are usually used as a reference material in various wear tests $[3,15,18,23-25]$. Thus, the information presented in our findings seems promising for comparing or evaluating the abrasion wear results reported by the literature, which also enables the transfer of the wear results into fabrication and operation conditions.

The majority of the proposed methods for abrasive wear prevention of steel components are a selection of wear resistant materials, surface layer modification and hardfacing with welding methods, deposition of wear resistant coatings or thin films. Still, hardfacing with Fe- [26], Ni- [27] or even Co-based [28] paddings is very popular for increasing resistance of steel substrate to various types of wear. However, the application of the welding technology is connected to high heat input into base metal substrate which results in structure deformation, inadequate dimensional accuracy and changes in the mechanical properties. Thus, the application of commercially available steel plates with wear-resistant padding weld (wear-resistant plates)) which are welded onto the machine parts [29] is an interesting solution. Moreover, recently the wear resistance of steel and other iron-based alloys has been enhanced by means of various advanced treatments. For example, ion implantation was used for increasing the wear resistance of Hardox and Raex steel [30], cast iron surface laser alloying with Ti powder was studied in [31], shoot peening surface modification [32] or surface engineering treatments such as fabrication of chromosiliconized layer on C45 steel [12]. Additionally, the thermal spray technology is applied to deposit the wear resistant coatings e.g. Latka et al. [15] conducted the research on the atmospheric plasma sprayed $\mathrm{Al}_{2} \mathrm{O}_{3}+13 \mathrm{wt} . \% \mathrm{TiO}_{2}$ ceramic coatings on X5CrNi18-10 substrate, in other work HVOF (High Velocity Oxygen Fuel) method was used to spray the $\mathrm{M}(\mathrm{Ni}, \mathrm{Co}) \mathrm{CrAlY}$ and $\mathrm{Cr}_{3} \mathrm{C}_{2}-\mathrm{NiCr}$ composite coatings onto stainless steel [33] or a flame sprayed Ni- and $\mathrm{Fe}$ - based coatings fabricated on mild steel and finally PVD or CVD thin films $[8,34]$ were considered for increasing the wear resistance. However, the selection for wear application of commercial steels seems to be still an up-to-date and unsolved problem. Even though the white cast irons abrasion resistance is unquestionable [31,35-37], the selection of resistant to abrasion steel remains a tricky task, especially taking into account the cost-effectiveness factor and outstanding structural properties of the steel.

Abrasive particles or grits are an inherent feature of many tribological systems [38]. Moreover, various abrasives are used and the test results are strongly influenced by the type and properties of abrasive material [1]. According to the literature [39], the standard natural abrasives are quartz, garnet, corundum and diamond, also the manufactured abrasives are fused aluminum oxides, zircona-aluminas, silicon carbide, boron carbide diamond (synthetic) or boron nitride. Unfortunately, these materials are usually used separately in the wear tests, which is supported by the literature $[3,5,11,17,25,40]$. Moreover, few papers compare the abrasive wear results with using natural and manufactured abrasives. 
The literature does not provide a systematic analysis of the effect of different abrasives on the resistance of steel; therefore, this work examines three different popular abrasives, namely: garnet, corundum and carborundum.

Hence, the main aim in this paper is to investigate the influence of garnet, corundum and carborundum grit materials on the abrasive wear result of the steels commonly used in industrial practice, namely S235JR, S355J2, C45, AISI 304 and Hardox 500.

\section{MATERIALS AND METHODS}

\section{Steel coupons used in abrasion testing}

The abrasive wear tests were performed on five steel grades: C45 (1.0503; AISI 1045), X5CrNi18-10 (1.4301; AISI 304); S235JR (1.0038); S355J2 (1.0577) and Hardox 500. First four grades are the steels used in machine building and the last one, Hardox 500 is a high strength structural steel dedicated for wear prevention applications. The description of test samples is given in Table 1. Before the tests, the structure and hardness of the test coupons were investigated. The structure was observed on the prepared metallographic samples with the usage of Nickon MA200 optical microscope and hardness was measured on the grind steel surfaces with Vickers method. The test coupons used for abrasion testing were machined from plates to obtain the dimensions of $5 \mathrm{~mm}$ x $29 \mathrm{~mm}$ × $29 \mathrm{~mm}$.

\section{Abrasive wear test}

The abrasion tests were conducted with the usage of T07 tribotester equipped with a rubber wheel (a dimension of $ø 44 \times 15 \mathrm{~mm}, 62$ revolutions of roll per minute) forced to the surface of test sample with $44 \mathrm{~N}$ load. The test stand is presented in Fig. 1. The abrasive was fed directly to the friction node. Three different abrasives were used: garnet, corundum (alumina) carborundum (silicon carbide). The morphology of the abrasives was studied with the usage of Keyence VHX 600 optical microscope. Additionally, the particle size distribution of grits was determined by sieving; therefore, the volume fraction and the average size of abrasives were estimated. The vibrating screen was used to conduct the sieve analysis according to the PN-83/H-11077 standard. Moreover, the grit size was classified according to the Federation of European Producers of Abrasives (FEPA) [41]. b)

The worn areas of steel samples were examined with a Nickon SMZ1500 stereoscopic microscope. The mass loss $\left(\mathrm{Z}_{\mathrm{w}}\right)$ was measured with $0.1 \mathrm{mg}$ accuracy with usage of WAS-222 balance. Abrasive wear test for each tested steel type was repeated three times; thus, in total, the data from 15 tests were collected and analyzed. Then, the mass $\operatorname{loss} \mathrm{Z}_{\mathrm{w}}$ was calculated according to formula:

$$
\mathrm{Z}_{\mathrm{w}}=\mathrm{m}_{1}-\mathrm{m}_{2}
$$

where: $m_{1}-$ specimen mass before wear testing $[\mathrm{g}]$

$m_{2}-$ specimen mass after wear testing $[\mathrm{g}]$

Table 1. Characterization of tested steel samples

\begin{tabular}{|c|c|c|c|c|c|c|}
\hline \multirow{2}{*}{\multicolumn{2}{|c|}{ Steel properties }} & \multicolumn{5}{|c|}{ Sample code ${ }^{a}$} \\
\hline & & \multirow{2}{*}{$\frac{C 45}{0.42-0.50}$} & \multirow{2}{*}{$\frac{\text { AISI } 304}{\max 0.07}$} & \multirow{2}{*}{$\frac{\text { S235JR }}{0.17}$} & \multirow{2}{*}{$\frac{\text { S355J2 }}{0.2}$} & \multirow{2}{*}{$\frac{\text { Hardox } 500}{\max 0.270}$} \\
\hline \multirow{8}{*}{$\begin{array}{c}\text { Chemical } \\
\text { composition, } \\
\text { wt } \%\end{array}$} & C & & & & & \\
\hline & $\mathrm{Si}$ & $0.17-0.37$ & $\max 1$ & & $\max 0.55$ & $\max 0.7$ \\
\hline & $\mathrm{Mn}$ & $0.50-0.80$ & $\max 2$ & $\max 1.40$ & $\max 1.6$ & $\max 1.6$ \\
\hline & $P$ & $\max 0.040$ & $\max 0.045$ & $\max 0.035$ & $\max 0.025$ & $\max 0.025$ \\
\hline & $S$ & $\max 0.040$ & $\max 0.015$ & $\max 0.035$ & $\max 0.025$ & $\max 0.01$ \\
\hline & $\mathrm{Cr}$ & $\max 0.30$ & $17-19.50$ & & $\max 0.3$ & $\max 1$ \\
\hline & $\mathrm{Ni}$ & $\max 0.30$ & $8-10.50$ & & $\max 0.3$ & $\max 0.25$ \\
\hline & Mo & $\max 0.10$ & & & & $\max 0.25$ \\
\hline \multicolumn{2}{|c|}{$\mathrm{Rm}, \mathrm{MPa}$} & 569 & $500-700$ & 340 & 490 & 1550 \\
\hline \multicolumn{2}{|c|}{$\mathrm{Re}, \mathrm{MPa}$} & 343 & 190 & 235 & 355 & 1400 \\
\hline \multicolumn{2}{|c|}{$\mathrm{A}_{5}[\%]$} & $14-17$ & 45 & $21-26$ & $20-22$ & 10 \\
\hline \multicolumn{2}{|c|}{ Density, $\mathrm{kg} / \mathrm{m}^{3}$} & 7850 & 8000 & 7800 & 7850 & 7850 \\
\hline
\end{tabular}




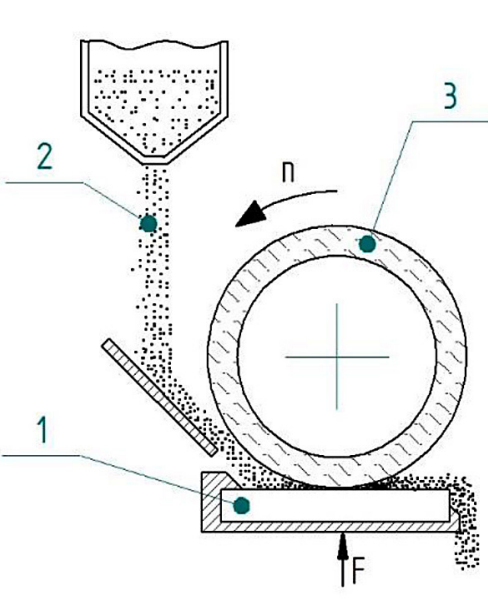

a)

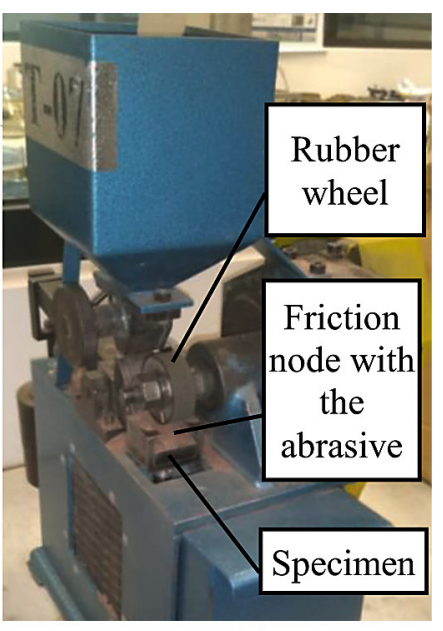

b)

Fig. 1. Dry sand-rubber wheel T-07 tribotester: a) scheme: 1 - sample, 2 - abrasive, 3 - rubber wheel; b) test rig

The C45 steel sample was used as a reference material. Therefore the average mass loss for the reference $C 45$ samples and other examined samples were named as $Z_{w w}$ and $Z_{w b}$, respectively.

$$
\begin{aligned}
& \mathrm{Z}_{\mathrm{ww}}=\frac{\sum_{\mathrm{i}=1}^{\mathrm{m}} \mathrm{Z}_{\mathrm{wi}}}{\mathrm{m}}[\mathrm{g}] \\
& \mathrm{Z}_{\mathrm{wb}}=\frac{\sum_{\mathrm{i}=1}^{\mathrm{m}} \mathrm{Z}_{\mathrm{wi}}}{\mathrm{m}}[\mathrm{g}]
\end{aligned}
$$

where: $m$ - total quantity of samples

$Z_{w i}$ - mass loss of each sample [g]

In order to calculate the relative abrasive wear resistance $\mathrm{K}_{\mathrm{b}}$ the volume material loss of reverence material $Z_{\mathrm{vw}}$ was divided by the volume loss of specific material $Z_{\mathrm{vb}}$ - both tested in the same test conditions.

$$
\mathrm{K}_{\mathrm{b}}=\frac{\mathrm{Z}_{\mathrm{vw}} \times N_{\mathrm{b}}}{\mathrm{Z}_{\mathrm{vb}} \times N_{\mathrm{w}}}=\frac{\mathrm{Z}_{\mathrm{ww}} \times \rho_{\mathrm{b}} \times N_{\mathrm{b}}}{\mathrm{Z}_{\mathrm{wb}} \times \rho_{\mathrm{w}} \times N_{\mathrm{w}}}[-]
$$

where: $Z_{w w}-$ mass loss of the reference specimen $(\mathrm{g})$

$Z_{w b}-$ mass loss of the examined specimen (g)

$\rho_{w}, \rho_{b}$ - weight wear of the reference and examined specimen $\left(\mathrm{g} / \mathrm{cm}^{3}\right)$

$N_{w}$ - number of roll revolutions for the reference specimen

$N_{b}$ - number of roll revolutions for the examined specimen.

\section{RESULTS AND DISCUSSION}

\section{Comparative analysis of abrasives and steel samples properties}

On the basis of the literature data in Table 2, the abrasives properties were characterized. It is known from the literature $[1,6]$ that the properties of the abrasive material influence the wear results. The hardness, shape and size of particles strongly affect the abrasion wear results. Generally, it can

Table 2. Typical properties of abrasives and calculated abrasive particles sizes

\begin{tabular}{|c|c|c|c|}
\hline Abrasives type & Garnet & Corundum & Carborundum \\
\hline Chemical composition & $\begin{array}{c}\text { iron aluminum silicate } \\
\mathrm{Fe}_{3} \mathrm{Al}_{2}\left(\mathrm{SiO}_{4}\right)_{3}\end{array}$ & $\begin{array}{c}\text { Aluminum oxide } \mathrm{Al}_{2} \mathrm{O}_{3} \\
\text { SiC }\end{array}$ & $\begin{array}{c}\text { Silicon carbide } \\
\mathrm{SiC}\end{array}$ \\
\hline Density $\left[\mathrm{g} / \mathrm{cm}^{3}\right]$ & $3.5-4.25$ & $3.9-4.0$ & $3.15-3.22$ \\
\hline Bulk density $\left[\mathrm{g} / \mathrm{cm}^{3}\right]$ & $2.2-2.5$ & $1.52-1.87$ & $1.30-1.58$ \\
\hline Grain shape & $\begin{array}{c}\text { Irregular shape with sharp } \\
\text { edges }\end{array}$ & $\begin{array}{c}\text { Irregular shape with } \\
\text { sharp edges }\end{array}$ & $\begin{array}{c}\text { Irregular shape with sharp } \\
\text { edges }\end{array}$ \\
\hline Hardness. HV [42] ${ }^{a}$ & $600-1355$ & 1800 & 2600 \\
\hline Hardness. Knoop K ${ }_{100}[39]^{\mathrm{a}}$ & 1360 & 2050 & 2480 \\
\hline Mohs hardness & $7-8.0$ & 9.0 & 9.5 \\
\hline Mean grain size $[\mathrm{mm}]$ & 0.18 & 0.10 & 0.05 \\
\hline
\end{tabular}

a Typical values. 
be summarized that high particles hardness, shape and size influence the wear results and are a function of metal alloys microstructure. Therefore, the abrasive materials applied in current study differ in properties. The sieve analysis allows estimating the size of abrasive particles, Fig. 2. Mean grain size of abrasives equals for garnet: $0.18 \mathrm{~mm}$, corundum: $0.1 \mathrm{~mm}$ and carborundum: $0.05 \mathrm{~mm}$. The results were analyzed in relation to the FEPA [41] standards: FEPA-Standard
42-1:2006 and FEPA-Standard 42-1:2006. The coarser grains were identified for garnet F80 (macrogrits acc. to FEPA) then. corundum with the grain value of F120 (macrogrits) and finally carborundum F230 - F240 which was composed of macrogrits and microgrits.

Though the comparative analysis of sieve experiment and micrographs of abrasives (Fig. 3), a garnet abrasive material presents fine and average grain size, the corundum is composed of a fine

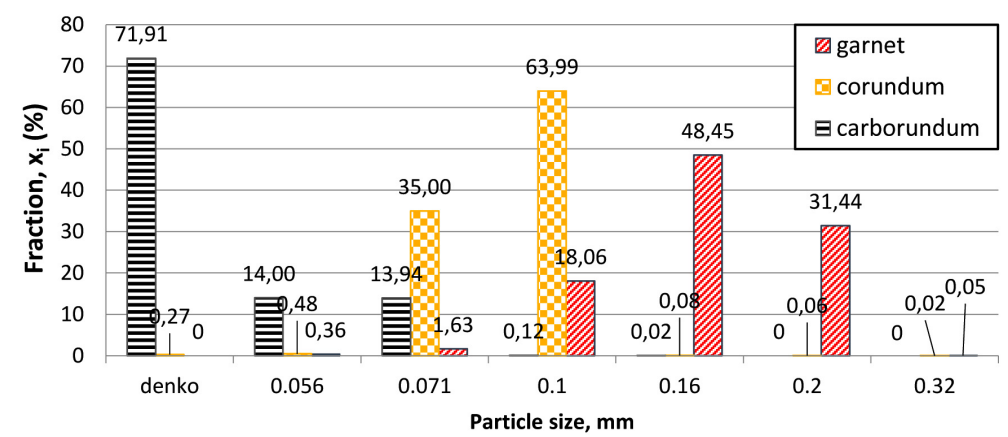

Fig. 2. Sieve analysis results of garnet, corundum and carborundum abrasives

a

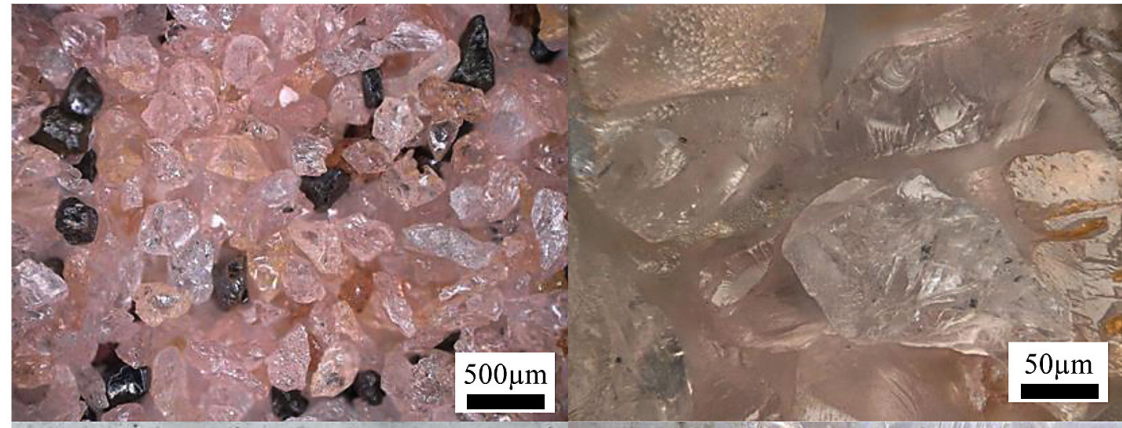

b)

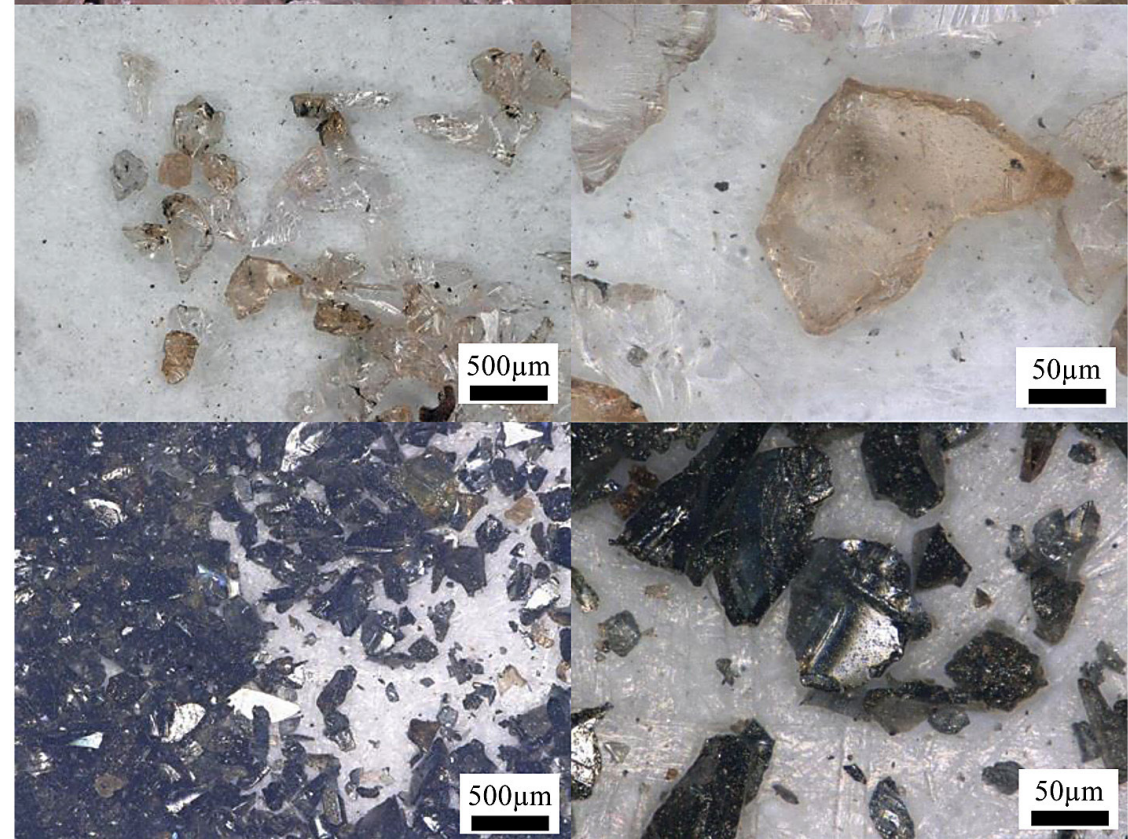

Fig. 3. Morphology of abrasive materials a) garnet. b) corundum. c) carborundum, VHX 600 microscope 
and very fine grains and carborundum presents very fine grains and micrograins. To sum up, in contrary to carborundum, garnet is the coarsest and the softest, Table 2. Fig. 3 shows that all abrasives presents irregular shape characterized by sharp edges, nevertheless the garnet grains seem much spherical and compact shape than the grains of carborundum and corundum.

\section{Microstructure and hardness of investigated steel}

The structure and hardness of the investigated steels are compared in Fig. 4 and Table 3 respectively. The S235JR and S355J2 low carbon structural steels present the ferritic structure with perlite, the S355J2 steel presents a higher content of carbon and finer grains than S235JR that contains more perlite and presents higher hardness which agrees with the literature [10]. The carbon steel, C45 presents normalized ferritic-prelatic structure and higher content of relatively hard perlite

Table 3. Vickers hardness of tested steel samples

\begin{tabular}{|c|c|}
\hline Sample code & Hardness, HV30 \\
\hline S235JR & $128 \pm 2$ \\
\hline S355J2 & $155 \pm 5$ \\
\hline AISI 304 & $211 \pm 7$ \\
\hline C45 & $229 \pm 3$ \\
\hline Hardox 500 & $521 \pm 15$ \\
\hline
\end{tabular}
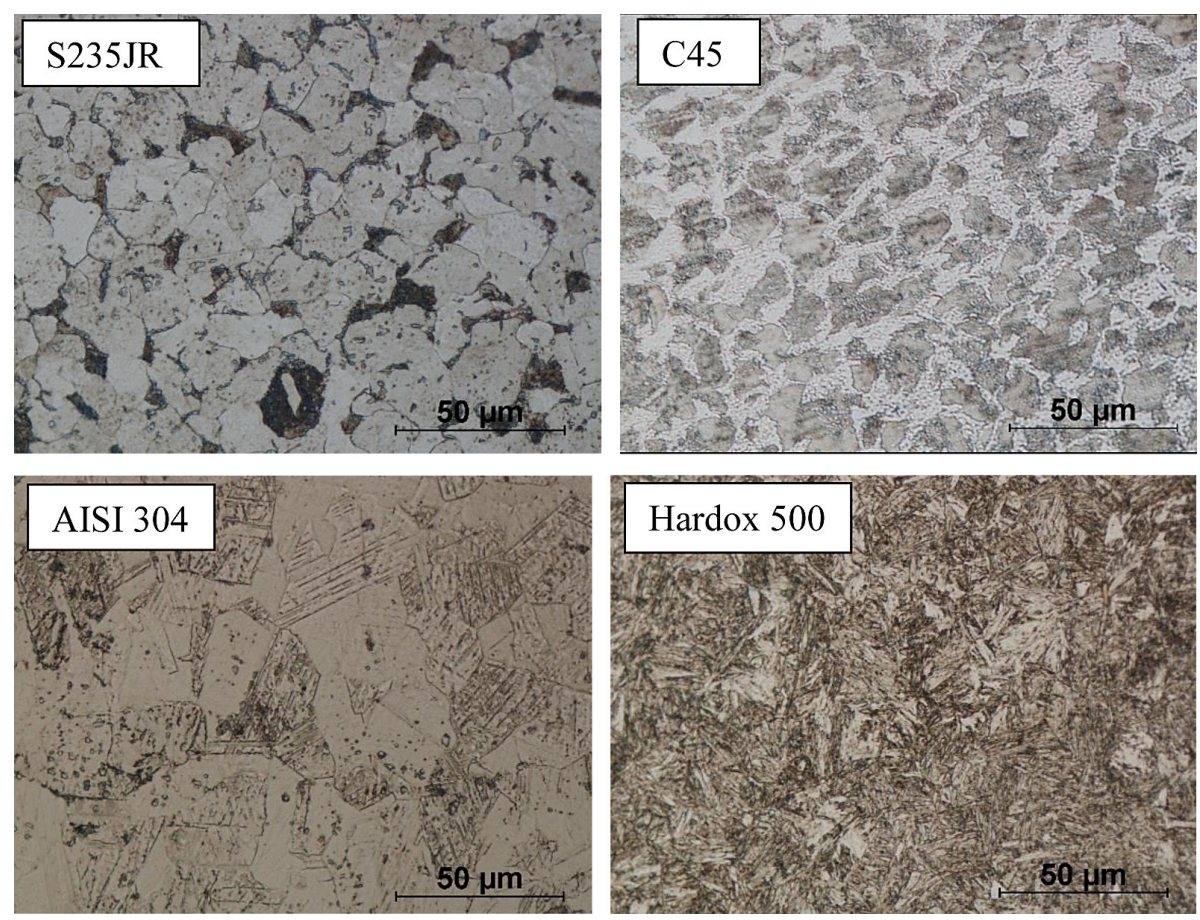

Fig. 4. Microstructure of investigated steels, LOM that effects the average hardness of 229 HV30, which is in agreement with the survey data [12]. As shown in Table 2. AISI 304 steel is a high alloyed stainless steel. Its structure is austenitic with typical austenite twinned grains (Fig. 4). Finally, Hardox 500 presents structure of tempered martensite without clear grain orders of the previous austenite comparable to the structure reported in the literature $[17,43]$. Due to the presence of a tough martensitic phase in its microstructure Hardox 500, the steel exhibits the outstanding hardness, at the similar to literature data level [4]. Summing up, the investigated steels differ in structure and hardness and their effects on abrasive wear results [1].

\section{Abrasive wear results}

During operation, the machine elements can be subjected to wear through contact with abrasive materials including soil, gravel, etc. In these cases, the grains can move relatively freely [4] and the rubber-wheel test simulates the real wear-operation conditions well.

The abrasive wear results are given in Fig. 5, Fig. 6 and in Table 4. It is clear that the same steel grade obtains different mass loss (Fig. 5) which confirms the effect of abrasive type on the resistance to wear. However, usually the usage of garnet results in the lowest and the carborundum the highest wear rate. Additionally, while analyzing 


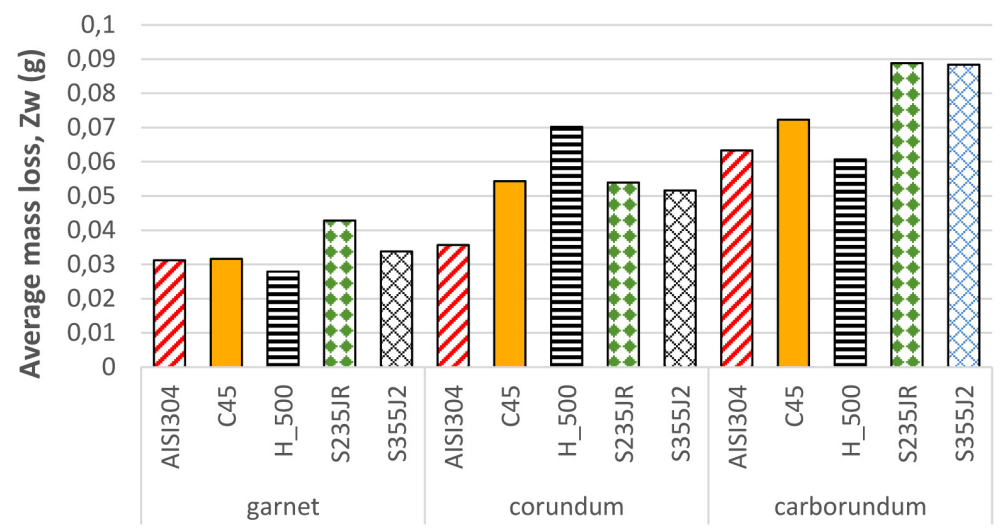

Fig. 5. Influence of various abrasives on wear of steels (garnet, corundum and carborundum)

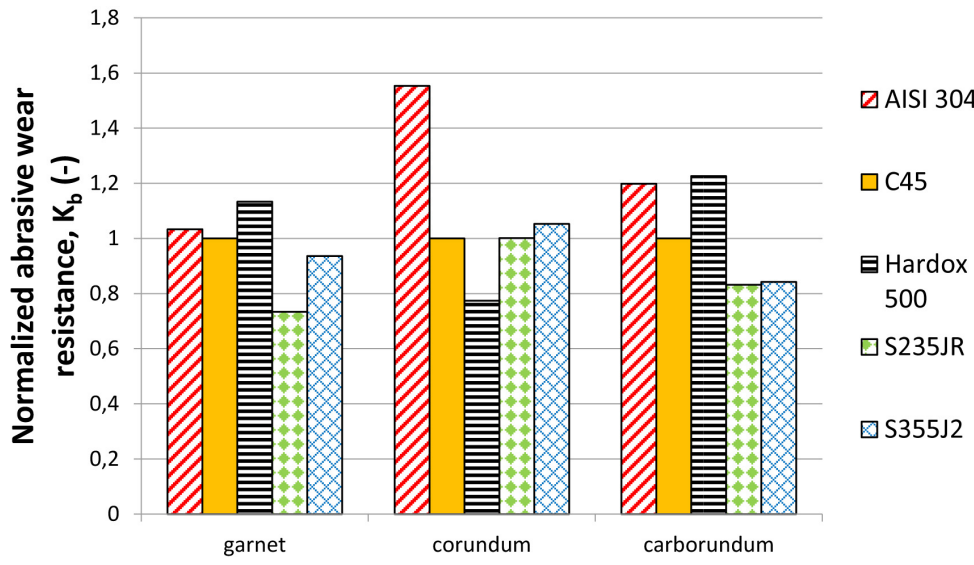

Fig. 6. Normalized abrasive wear resistance estimated for different abrasives in relation to C45 steel

the normalized abrasive wear resistance $(K b)$ with relation to three different abrasives: garnet. corundum and carborundum (Fig. 6), it can be deduced that none of the investigated materials presents universally outstanding wear resistance. In other words, the selection of the materials for specific operating conditions should involve the wear tests with the usage specific abrasive material under the working conditions that are similar to the actual ones, because transferring of the results can be burdened with high error. For example, Hardox 500 steel presents superior resistance to abrasion with garnet and carborundum but inferior resistance to corundum also the $K b$ value of Hardox 500 tested in corundum is on comparable level as in the work [18]. As was discussed in the previous section, the investigated steels present various microstructure (ferritic-pearlitic, austenitic and martensitic) and hardness. Thus, combining the analysis of structures from Fig. 4 and wear results allows stating the wear resistance of steels is related to their microstructure, see Table 4.

Summing up, the tests conducted with garnet and carborundum demonstrate a similar trend i.e. ferritic-pearlitic structures are less resistant than martensitic steel. On the other hand, the austenitic AISI 304 steel presents a superior wear resistance and is easily abraded while testing with corundum. It can be explained by the fact that garnet is a soft relative to the martensitic structures and does not abrade steels as effectively as hard corundum. Additionally, garnet is hard relative to steels, and

Table 4. Wear resistance results in relation to the steel structure

\begin{tabular}{|c|c|c|}
\hline \multirow{2}{*}{$\begin{array}{l}\text { Abrasive } \\
\text { material }\end{array}$} & \multicolumn{2}{|c|}{ Abrasive wear resistance } \\
\hline & Steel & microstructure \\
\hline garnet & S235JR < S355J2 < C45 < AISI $304<$ Hardox 500 & ferrite+pearlite $<$ austenite $<$ martensite \\
\hline corundum & Hardox $500<$ S235JR = C45<S355J2<AISI 304 & martensite $<$ ferrite + pearlite $<$ austenite \\
\hline carborundum & $\mathrm{S} 235 \mathrm{JR}=\mathrm{S} 355 \mathrm{~J} 2<\mathrm{C} 45<\mathrm{AISI} 304<$ Hardox 500 & ferrite+pearlite $<$ austenite $<$ martensite \\
\hline
\end{tabular}


it abrades untreated steels with nearly the same aggressiveness as corundum and carborundum. It is in compliance with the finding reported for the cast irons by the literature [42].

Figure 7 shows the effect of steel hardness on the mass loss. Although the effect of the abrasive grains size on the wear results of the steel was not acclaimed, Fig. 8 shows the influence of abrasives hardness on the steel mass loss. It is acknowledged that the wear resistance of S235, S355, and C45 carbon steels increases with hardness and content of carbon, see Fig. 9. However, due to its structure i.e. austenitic of AISI 304 and tempered martensite of Hardox 500, these samples do not inscribe to plots given in Fig. 7.

The wear traces analysis was conducted with the stereoscope microscope, see Fig. 10. Abrasive materials present different properties as well as the structure and hardness of the steels differ from each other. Thus, the wear occurring due to hard particles in the carborundum and corundum results in the microcutting-scratching wear mechanism of steels (domination of microcutting, characterized by the long groves), contrary to the relatively coarse and soft garnet particles resulting in the scratching-microcutting wear mechanism (with fine groves).

\section{CONCLUSIONS}

The paper investigates the influence of different abrasive grit materials i.e. garnet, corundum, and carborundum on the abrasive wear result of steels typically used in the industrial practice i.e. S235, S355, C45, AISI 304, and Hardox 500.

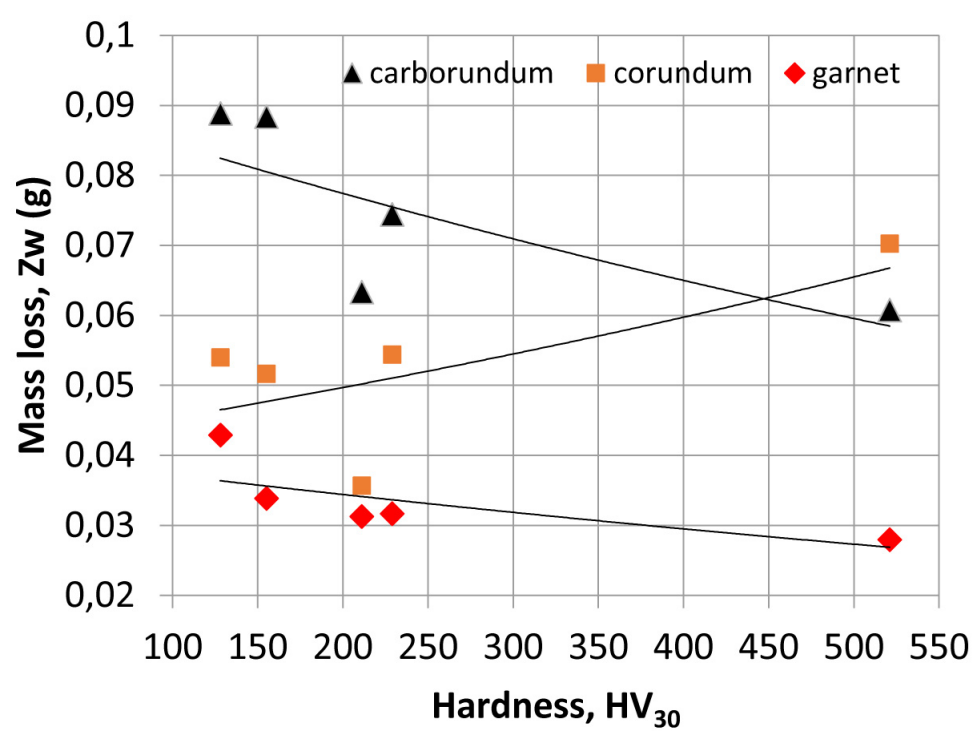

Fig. 7. Influence of steel hardness on the abrasive wear results

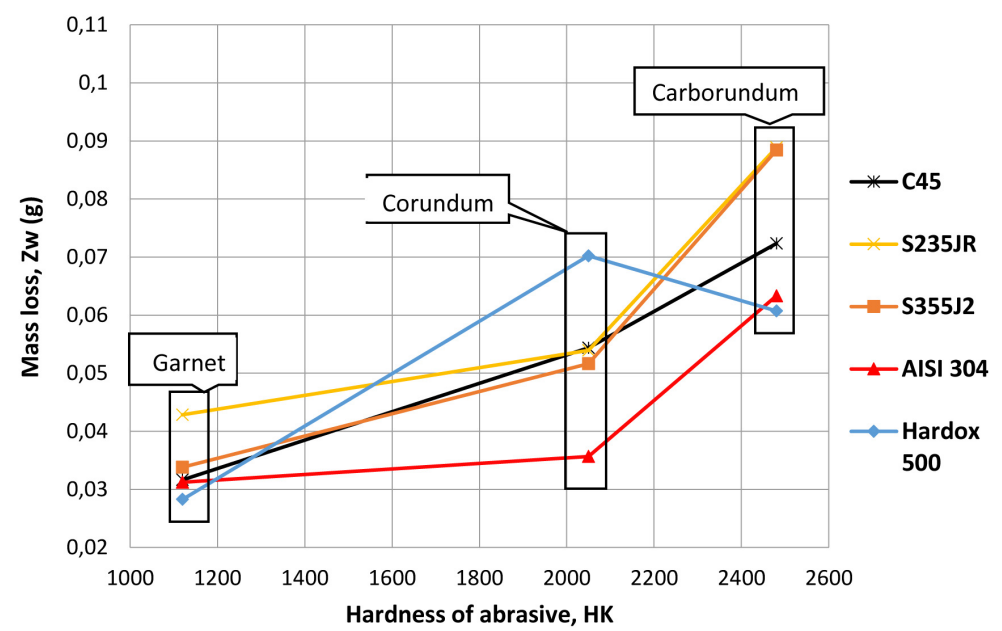

Fig. 8. Effect of abrasive hardness on the wear results 


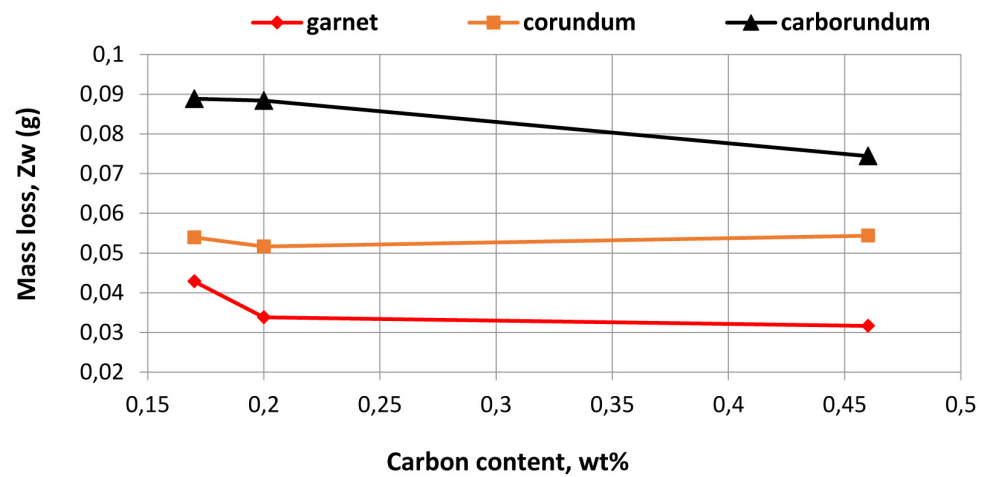

Fig. 9. Effect of carbon content on the wear resistance of carbon steel S235JR, S355J2 and C45

The studies confirmed that the abrasive wear depends on the material and morphology (shape and size of particles) of the abrasive as well as the hardness and structure of steel. On the basis of the test results, it can be determined that the garnet is useful as a material for abrasion resistance investigate. Abrasive wear with a garnet causes a smaller weight loss of the tested specimens than for the wear with corundum or carborundum, which can be explained by the hardness of corundum and carborundum superior to garnet.
The highest mass loss was obtained for garnet, corundum, and carborundum, respectively. The usage of various abrasives gives different abrasion resistance results of each tested steel type. The AISI 304 austenitic stainless steel presents outstanding abrasive wear resistance while testing in corundum; on the other hand, Hardox 500 exhibits the highest abrasion resistance while testing in garnet. The C45 carbon steel was less resistant than the AISI 304 grade for all three examined abrasives. The lowest resistance to wear

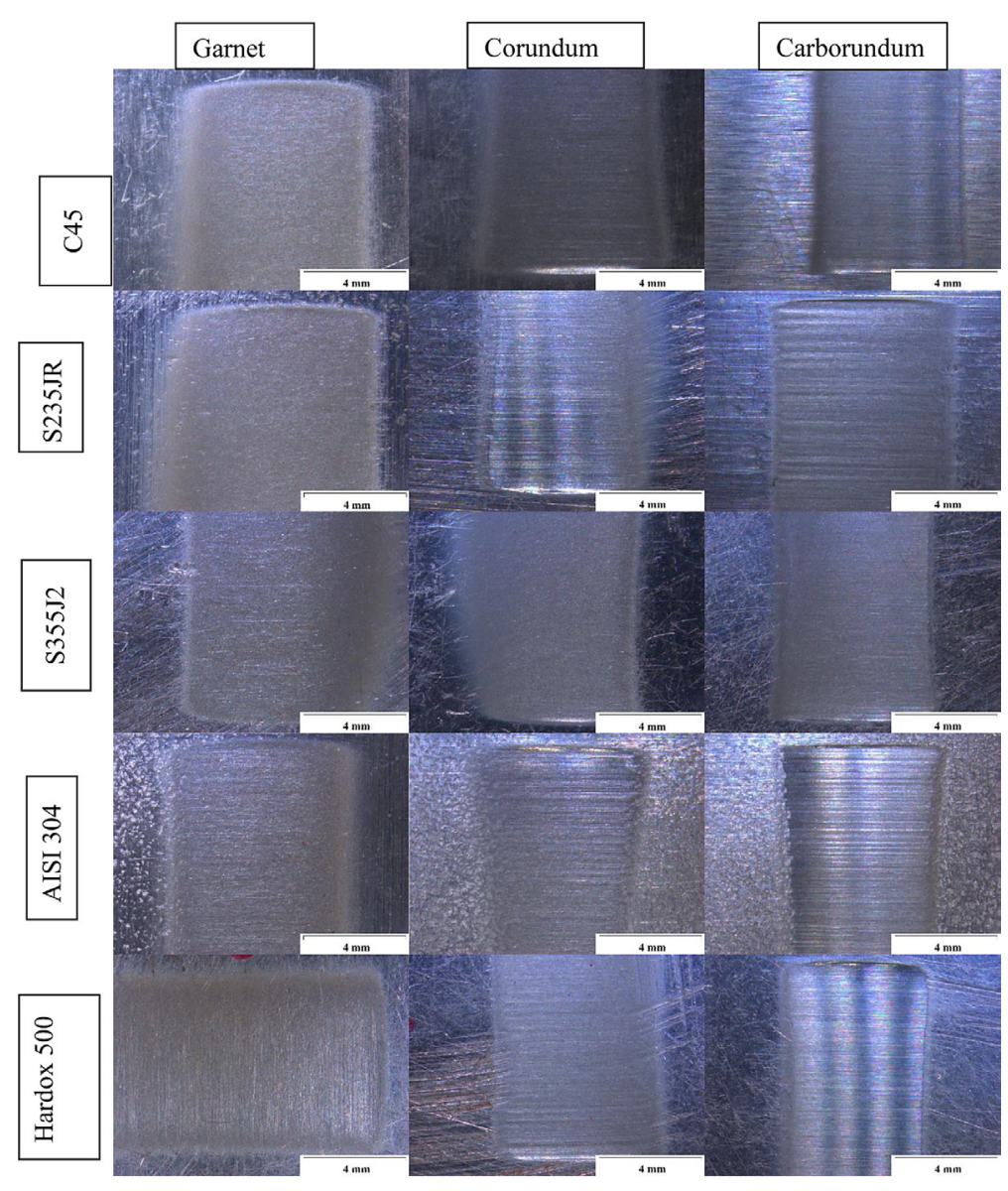

Fig. 10. Exemplary wear traces (4 mm marker), stereoscope microscope. 
in garnet, carborundum were indicated for the S235JR and S355J2 ferritic-pearlitic carbon steels and in corundum for Hardox 500 with tempered martensite structure. The abrasive wear behaviors were dominated by the microscratching-microcutting wear mechanism.

This study points out that steels grades austenitic 304, Hardox 500 and structural C45 are characterized by high abrasion resistance. The S235JR and S355J2 steels have low abrasion resistance. The Hardox 500 steel is the most attractive due to the use in machine parts exposed to the abrasive wear, because at present, the market price of this steel is approx. half of AISI 304. However, it should be borne in mind that Hardox steel has a low resistance to abrasiveness by corundum.

\section{Acknowledgement}

The research was financed in the framework of the project Lublin University of Technology - Regional Excellence Initiative. funded by the Polish Ministry of Science and Higher Education (contract No. 030/RID/2018/19).

\section{REFERENCES}

1. K.-H.Z. Gahr, Microstructure and Wear of Materials, Elsevier, 1987.

2. J. Rendón, M. Olsson, Abrasive wear resistance of some commercial abrasion resistant steels evaluated by laboratory test methods, Wear. 267 (2009) 20552061. https://doi.org/10.1016/j.wear.2009.08.005.

3. M. Szala, A. Dudek, A. Maruszczyk, M. Walczak, J. Chmiel, M. Kowal, Effect of atmospheric plasma sprayed $\mathrm{TiO} 2-10 \% \mathrm{NiAl}$ cermet coating thickness on cavitation erosion, sliding and abrasive wear resistance, Acta Phys. Pol. A. 136 (2019) 335-341. https://doi.org/10.12693/APhysPolA.136.335.

4. W. Tarasiuk, J. Napiorkowski, K. Ligier, B. Krupicz, COMPARISON OF THE WEAR RESISTANCE OF HARDOX 500 STEEL AND 20MnCr5, Tribologia. 273 (2017) 165-170. https:// doi.org/10.5604/01.3001.0010.6254.

5. M. Adamiak, G. Jacek, T. Kik, Comparison of abrasion resistance of selected constructional materials, Journal of Achievements in Materials and Manufacturing Engineering. 37 (2009).

6. T. Hejwowski, Nowoczesne powłoki nakładane cieplnie odporne na zużycie ścierne i erozyjne, Politechnika Lubelska, Lublin, 2013. http://bc.pollub. $\mathrm{pl} /$ dlibra/docmetadata? $\mathrm{id}=4059$.

7. L. Nedeloni, Z. Korka, D. Pascal, N. Kazamer, M. Nedeloni, Comparative Study on Dry Sliding Wear Resistance of Carbon Steel, Alloyed Steel and Cast
Iron, in: 2018: p. 012026. https://doi.org/10.1088/1 757-899X/416/1/012026.

8. M. Szala, M. Walczak, K. Pasierbiewicz, M. Kamiński, Cavitation Erosion and Sliding Wear Mechanisms of AlTiN and TiAlN Films Deposited on Stainless Steel Substrate, Coatings. 9 (2019) 340. https://doi.org/10.3390/coatings9050340.

9. O.A. Zambrano, Y. Aguilar, J. Valdés, S.A. Rodríguez, J.J. Coronado, Effect of normal load on abrasive wear resistance and wear micromechanisms in FeMnAlC alloy and other austenitic steels, Wear. 348-349 (2016) 61-68. https://doi.org/10.1016/j. wear.2015.11.019.

10. Md.A. Islam, T. Alam, Z. Farhat, A.M.A. Mohamed, A. Alfantazi, Effect of microstructure on the erosion behavior of carbon steel, Wear. (2014). https://doi. org/10.1016/j.wear.2014.12.004.

11. T. Hejwowski, S. Szewczyk, A. Weroński, An investigation of the abrasive and erosive wear of flame-sprayed coatings, Journal of Materials Processing Technology. 106 (2000) 54-57. https://doi. org/10.1016/S0924-0136(00)00638-5.

12. I. Bauer, Microstructure and Resistance to Abrasive and Corrosive Wear of a Chromosiliconized Layer on C45 Steel Substrate, Tribologia. nr 1 (2019). http://yadda.icm.edu.pl/yadda/element/bwmeta1. element.baztech-4f3450ef-c316-43cb-a8df-56c23 55b09af (accessed September 23, 2019).

13. M. Szala, K. Beer-Lech, M. Walczak, A study on the corrosion of stainless steel floor drains in an indoor swimming pool, Engineering Failure Analysis. 77 (2017) 31-38. https://doi.org/10.1016/j. engfailanal.2017.02.014.

14. M. Banaszkiewicz, A. Rehmus-Forc, Stress corrosion cracking of a $60 \mathrm{MW}$ steam turbine rotor, Engineering Failure Analysis. 51 (2015) 55-68. https:// doi.org/10.1016/j.engfailanal.2015.02.015.

15. L. Łatka, M. Szala, M. Michalak, T. Pałka, Impact of atmospheric plasma spray parameters on cavitation erosion resistance of $\mathrm{Al} 2 \mathrm{O} 3-13 \% \mathrm{TiO} 2$ coatings, Acta Phys. Pol. A. 136 (2019) 342-347. https://doi.org/10.12693/APhysPolA.136.342.

16. O.A. Zambrano, J.A. Gómez, J.J. Coronado, S.A. Rodríguez, The sliding wear behaviour of steels with the same hardness, Wear. 418-419 (2019) 201207. https://doi.org/10.1016/j.wear.2018.12.002.

17. Ł. Konat, B. Białobrzeska, P. Białek, Effect of Welding Process on Microstructural and Mechanical Characteristics of Hardox 600 Steel, Metals. 7 (2017) 349. https://doi.org/10.3390/met7090349.

18. B. Białobrzeska, Ł. Konat, Comparative analysis of abrasive-wear resistance of Brinar and Hardox steels, Tribologia. nr 2 (2017). http://yadda.icm. edu.pl/baztech/element/bwmeta1.element.baztec h-e4396f46-dd62-47c9-aef6-f785d1504c04 (accessed September 24, 2019).

19. W. Macek, Post-failure fracture surface analysis of notched steel specimens after bending-torsion fatigue, Engineering Failure Analysis. 105 
(2019) 1154-1171. https://doi.org/10.1016/j. engfailanal.2019.07.056.

20. D. Fydrych, A. Świerczyńska, G. Rogalski, J. Łabanowski, Temper Bead Welding of S420G2+M Steel in Water Environment, Advances in Materials Science. 16 (2016) 5-16. https://doi.org/10.1515/ adms-2016-0018.

21. W. Macek, T. Wołczański, Analysis of fracture roughness parameters of $\mathrm{S} 355 \mathrm{~J} 2$ steel and EN AW-2017A-T4 aluminium alloy, ITM Web Conf. 15 (2017) 06002. https://doi.org/10.1051/ itmconf/20171506002.

22. M. Kłonica, Comparative analysis of effect of thermal shock on adhesive joint strength, Adv. Sci. Technol. Res. J. 10 (2016) 263-268. https://doi. org/10.12913/22998624/66509.

23. U. Alonso Pinillos, S.R. Fernández Vidal, M. Calamaz, F.A. Girot Mata, Wear Mechanisms and Wear Model of Carbide Tools during Dry Drilling of CFRP/TiAl6V4 Stacks, Materials. 12 (2019) 2843. https://doi.org/10.3390/ma12182843.

24. M. Szala, T. Hejwowski, Cavitation Erosion Resistance and Wear Mechanism Model of Flame-Sprayed Al2O3-40\% TiO2/NiMoAl Cermet Coatings, Coatings. 8 (2018) 254. https://doi. org/10.3390/coatings8070254.

25. M. Karpets, V. Gorban', O. Myslyvchenko, S.V. Marchenko, N.A. Krapivka, Effect Of Nickel Content On Wear Resistance Of Cast High-entropic Alloy VCrMnFeCoNix, Современная Электрометаллургия. 2015 (2015) 56-60. https:// doi.org/10.15407/sem2015.01.09.

26. K. Dziedzic, M. Pashechko, M. Barszcz, J. Józwik, Structure and Construction Assessment of the Surface Layer of Hardfaced Coating after Friction, Adv. Sci. Technol. Res. J. 11 (2017) 253-260. https://doi.org/10.12913/22998624/76583.

27. T. Hejwowski, K. Marczewska-Boczkowska, A. Kobayashi, A comparative study of electrochemical properties of metallic glasses and weld overlay coatings, Vacuum. 88 (2013) 118-123. https://doi. org/10.1016/j.vacuum.2012.02.031.

28. M. Szala, T. Hejwowski, I. Lenart, Cavitation erosion resistance of $\mathrm{Ni}-\mathrm{Co}$ based coatings, Adv. Sci. Technol. Res. J. 8 (2014) 36-42. https://doi. org/10.12913/22998624.1091876.

29. M. Szymura, M. Różański, The influence of positioning deposited beads towards direction of abrasive movement, to resistance on grind wear plates' abrasive wear, Welding Technology Review. 91 (2019). https://doi.org/10.26628/wtr.v91i5.1030.

30. P. Budzyński, M. Kamiński, K. Pyszniak, The influence of nitrogen ion implantation on the tribological properties of piston rings made of Hardox and Raex steels, IOP Conf. Ser.: Mater. Sci. Eng. 148 (2016) 012044. https://doi.org/10.1088/1757-89 9X/148/1/012044.

31. D. Janicki, Microstructure and Sliding Wear Behaviour of In-Situ TiC-Reinforced Composite
Surface Layers Fabricated on Ductile Cast Iron by Laser Alloying, Materials. 11 (2018) 75. https://doi. org/10.3390/ma11010075.

32. W. Macek, M. Szala, M. Kowalski, J. Gargasas, A. Rehmus-Forc, A. Deptuła, Shot peening intensity effect on the bending fatigue strength of S235, S355 and P460 steels, IOP Conf. Ser.: Mater. Sci. Eng. in print (2019).

33. M. Szala, M. Walczak, Cavitation erosion and sliding wear resistance of HVOF coatings, Welding Technology Review. 90 (2018). https://doi. org/10.26628/wtr.v90i10.964.

34. B. Olofinjana, U.S. Mbamara, O. Ajayi, C. Lorenzo-Martin, E.I. Obiajuuwa, E.O.B. Ajayi, Tribological behavior of $\mathrm{N}$-doped $\mathrm{ZnO}$ thin films by metal organic chemical vapor deposition under lubricated contacts, Friction. 5 (2017) 402-413. https://doi. org/10.1007/s40544-017-0154-x.

35. L. Lu, H. Soda, A. McLean, Microstructure and mechanical properties of $\mathrm{Fe}-\mathrm{Cr}-\mathrm{C}$ eutectic composites, Materials Science and Engineering A. 347 (2003) 214-222. https://doi.org/10.1016/ S0921-5093(02)00588-9.

36. S.S. Mandal, K.S. Ghosh, D.K. Mondal, Correlation between microstructure, hardness, wear and electrochemical behaviour in $8.0 \%, 16.0 \%$ and $20.0 \%$ (by wt) chromium white irons, Materials Chemistry and Physics. 193 (2017) 401-412. https://doi. org/10.1016/j.matchemphys.2017.02.041.

37. S.W. Watson, B.W. Madsen, S.D. Cramer, Wear-corrosion study of white cast irons, Wear. 181-183, Part 2 (1995) 469-475. https://doi.org/10.1016/0 043-1648(95)90160-4.

38. G.W. Stachowiak, A.W. Batchelor, Engineering tribology, Elsevier Butterworth-Heinemann, Amsterdam; Boston, 2005. http://www.engineeringvillage.com/controller/servlet/OpenURL?genre=book \&isbn=9780750678360 (accessed June 12, 2013).

39. J.-C. Menard, N.W. Thibault, Abrasives, in: Ullmann's Encyclopedia of Industrial Chemistry, American Cancer Society, 2000. https://doi. org/10.1002/14356007.a01_001.

40. C.-M. Chang, Y.-C. Chen, W. Wu, Microstructural and abrasive characteristics of high carbon $\mathrm{Fe}-\mathrm{Cr}-\mathrm{C}$ hardfacing alloy, Tribology International. 43 (2010) 929-934. https://doi.org/10.1016/j. triboint.2009.12.045.

41. Federation of European Producers of Abrasives (FEPA), (n.d.). https://www.fepa-abrasives.com/ (accessed September 19, 2019).

42. R.B. Gundlach, J.L. Parks, Influence of abrasive hardness on the wear resistance of high chromium irons, Wear. 46 (1978) 97-108. https://doi.org/10.1 016/0043-1648(78)90113-8.

43. S. Frydman, Ł. Konat, G. Pękalski, Structure and hardness changes in welded joints of Hardox steels, Archives of Civil and Mechanical Engineering. 8 (2008) 15-27. https://doi.org/10.1016/ S1644-9665(12)60118-6. 